\title{
ENSAIOS GEOELÉTRICOS 2D NO ANTIGO LIXÃO DE RIBEIRÃO PRETO - SP: AVALIAÇÃO DE PARÂMETROS DE AQUISIÇÃO E MONITORAMENTO AMBIENTAL DO PROBLEMA
}

\author{
Sergio Junior da Silva Fachin \\ Orientador: Dr. Vagner Roberto Elis (IAG-USP) \\ 142 p. - Dissertação (Mestrado) - Defesa 14.09.2007
}

RESUMO. Em razão da crescente preocupação com a proteção ao meio ambiente e preservação da qualidade das águas superficiais e subterrâneas, as áreas de disposição de resíduos, tanto domésticos como industriais, têm merecido especial atenção das instituições de pesquisa ligadas à proteção ambiental. Atualmente o uso dos métodos geoelétricos vem se destacando como metodologia indireta de investigação de áreas afetadas pela disposição inadequada de resíduos sólidos urbanos e industriais pois fornecem, desde que adequadamente escolhidas as técnicas e os parâmetros de aquisição, informações importantes com respeito à localização e geometria dos depósitos de resíduos, extensão da pluma de contaminação, posição da zona saturada e sentido do fluxo subterrâneo, características litológicas e presença de estruturas geológicas. A integração de ferramentas como simulações e métodos de interpretação qualitativa e quantitativa também auxiliam na caracterização e monitoramento ambiental de áreas de disposição de resíduos sólidos. 0 objetivo principal deste trabalho foi a avaliação de alguns parâmetros de aquisição 2D (arranjos eletródicos, espaçamento entre eletrodos e níveis de investigação) com os métodos da Eletrorresistividade e da Polarização Induzida, para caracterização e monitoramento ambiental. Esta avaliação foi realizada através do uso de modelagens diretas bidimensionais e ensaios de campo, tendo como área de estudos o antigo lixão do município de Ribeirão Preto - SP. 0 uso das modelagens diretas permitiu escolher os melhores parâmetros de aquisição de acordo com as respostas obtidas pelo modelo geológico-geofísico simulado. Os parâmetros de aquisição testados em campo refletiram os resultados obtidos através das modelagens diretas. 0 arranjo Polo-dipolo $(a=5$ metros e $n=10)$ apresentou os melhores resultados (melhor resolução lateral e maior profundidade de investigação). Os resultados obtidos com as investigações de campo comparados com resultados anteriores (1997), mostraram que ainda há contaminação, marcada por baixos valores de resistividade elétrica (1 a 30 0hm.m) e altos valores de cargabilidade (15 a 50 mV/V).

ABSTRACT. Due to the increasing concern with the environmental protection and preservation of the shallow water and groundwater aquifers quality, the areas of disposal of residues, have been special attention of the environmental protection agency. Currently the geoelectrical methods have been largely used as an investigation non-evasive methodology in affected areas by inadequate disposal of urban solid and industrial residues, because it provides information of the localization and geometrical characteristics of the waste disposal, contamination plume extent, saturated zone position, underground flow direction and geologic characteristic, if the techniques and the acquisition parameters are adequately chosen. The simulations and interpretation methods also assist during the characterization and environmental monitoring of landfill areas. The objective of this research was the evaluation of the acquisition field parameters (electrodes arrays, electrodes spacing and number of the investigations levels) and $2 \mathrm{D}$ investigations with the resistivity and induced polarization methods for characterization and environmental monitoring. This evaluation was carried through the use of 2D forward modeling and field investigations in old landfill site at Ribeirão Preto city, São Paulo, Brazil. The use of the forward modeling allowed to choose the best field acquisition parameters in accordance with the answers for the geologic-geophysical simulated model. The comparison between our results and previous results showed contamination marked for low electric resistivity values (1-30 0hm.m) and high chargeability values (15-50 mV/V) and also that the tested parameters of acquisition in agreement with the results of the forward modeling. The Pole-dipole array $(a=5$ meters and $n=10$ ) show the best result (resolution image and investigation depth), forward modelling and field acquisition. 